\title{
Poetic Lexicon At Andalusia Feminist Poetry
}

\author{
Assistant Professor Dr. Muneer Obaid Najm
}

University of Babylon, College of Basic Education, Hillah, Iraq. moneernajem@gmail.com

\begin{abstract}
Every poet has a set of vocalizations that he used to use in his poetry until it became his own stylistic feature, and Ibn Rashiq Al-Qayrawani referred to this idea in his saying, "The well-known poets are well-known and familiar examples that the poet should not prepare nor use any other" (1). Each poet has his own language that distinguishes him from other poets, and they are multi-cultural and literary. They take care of it, as it represents the basic element of building poetry. Lexical even carries a great aura of synonym It has congeners (2), for each creative product has its own linguistic texture in which the poet uses a special use in what his spiritual experience interacts with and intensifies in its accomplishment of his artistic ability and his philosophy of using language to reveal the spirit of renewal and the power of poetic (3), and by this, he may come out with words from Its established nature with its frozen dictionary conditions to a new nature imposed on it by the development of meanings and connotations that the poetic experience underwent in the same poet was subjected to formulate his poetic experience, realizing in the same reader and listener a delicious presence and repercussion (4), and the skillful poet is the one who can formulate from the word what he wants and give it Hair heat.

The headmaster of the poetic dictionary of the Andalusian poet finds that the word varies with the contrast of the subject that you are dealing with. For example, spinning requires words characterized by tenderness and sweetness, while rough preaching requires a luxurious sentence and the situation with praise, and if we find that the Andalusian poet has participated in most poetry arts and recorded thin poems in Most of its doors were used to flirt with a man just as it does in a man, and they were praised, spoiled and inherited in a manner similar to that of the man (5).

Therefore, we found it appropriate to address the feminist Andalusian poetic lexicon, according to the purposes that the Andalusian poet addressed and became famous for.
\end{abstract}

Article Received: 18 October 2020, Revised: 3 November 2020, Accepted: 24 December 2020

\section{First: Glossary of praise}

And it is one of the most prominent purposes of poetry, but rather the stumping of its poets. Poets used the word poem for praise poetry in the preprehistoric era and its significance expanded to include all other poetic purposes. Ibn Rashiq AlQayrawani These virtues have four categories: mind, chastity, justice, and courage (6). Examining the glossary of praise in Andalusian feminist poetry finds that the Andalusian poet has mastered in all its colors, especially political praise, praising the various classes of kings and ministers to achieve their own desire, and the reason for this is to encourage Andalusian caliphs who were known for their broad culture and their unlimited support for poets (7), The number of praise verses in the total Andalusian feminist poetry has reached (78) verses, and the glossary of praise in Andalusian feminist poetry can be studied through the dualism of its praise and praise.

\section{1- Al Mamdouh}

The central axis around which praise is spoken revolves and in this field various features emerge, all of which fall within the circle of moral virtues and lofty attributes that were and still are respected and valued by all. Among these advantages is the virtue (generosity, courage). In the field of generosity, words such as (Al-Joud, Al-Nada, Al-Mann) are hesitant, among which are the words of Hassaneh Al-Tamimiyyah praising Prince Abdul-Rahman except in the middle (8)

To the dew and glory, my chariots walked along a path that prayed with the fires of immigration

The poet's imagination made the character of generosity limited to the person praised until it 
became a note intended by the stirrups, despite the difficulty of the destination.

And the saying of Umm Al-Hassan Al-Sanjali in praising one of the kings of sects (9)

If it is said that among the people in the Lord of His virtue

he has the Almighty and the glory of it is authentic

So, Radwan Wahid said his time that time is the same for stingy

The poet made Mamdouh his only time in generosity and generosity.

On the level of courageous words, the words (the great, the slander, the poison, the clauses, the whites) emerge, including the words of Aisha alQurtubi (10)

The horses excited him and shook

the sense of humor and brightened the items

And how to disappoint a cub that has grown

to the upper black pigmentation

So you are Al-Amir, the best of

the Zakat sons and grandparents

The poet's imagination has added to the inanimate human qualities that exaggerate the praise of the caliph. Seeking to perpetuate the image of the hero presented in the mind of the recipient.

The matter is repeated in the words of Maryam bint Abi Yaqoub praising Prince Al-Mahdi (11).

Marwan liked those who raided his deposits

and found and became good examples

Whoever was his father, the Muhannad alMuhannad,

was not born from the chaff, but the white one

Al-Mamdouh compared the sword in his courage, how not. He descended from a dynasty known for strength and feet, so it has become self-evident that he descends from that aroma is the analogy of (eggs, descendants) / Prince Al-Mahdi. And the manufacture of weapons abundant in the military machines, and the overseer in the Mamdouh dictionary $\mathrm{He}$ finds himself decorated with the words of holiness and reverence for the person praised as (Khair al-Wari, Imam, al-Hashemi) as the words of Hasana al-Tamimi (12)
Say forward, delay the last proportions

between parents and grandparents

$O$ Bin Al-Hashemi, the best of mankind is the best of manners and the best of manners for one day

2- Praise:

The character of the praise oscillates between appearing and being absent, depending on the nature of his praise, as it recedes or is absent in the poem. In exchange for this decline, the character of Al-Mamdouh who praises him praises images of praise and praise, and pictures of praise appear in two images:

A - Request for Bid: In which the praise appears at the end of the poem asking for the bid, so the words are repeated (painful, panic, thankfulness)

His words of Hassan al-Tamimi (13)

I am to you, Aba Al-Asi, a painful father, to Hussein, who gave him the long-standing stalker I have grown up in his blissful shade, so today I harbor your blessings

The poet complains about losing her father at the time she turns around giving, so she used to double praise with a clear thread of giving and asking for money, including the statement of Mary, the daughter of Abi Yaqoub: (14)

Whoever comes with you to say and inaction, and you have looked to the credit and did not go away My money thanked you who organized in my neck from the machine and what was given to me from my heart

You sweetened me with jewelry that became bright with every female holiday

As the poet begins by preferring the wage to Prince Mahdi over what he has for his benign attributes and qualities, then she goes through to her goal of asking Nawal through her statement that she is unable to thank Nawal.

B- The complaint addressed to Al-Mamdouh: This appears through the occurrence of the words containing the complaining and complaining, such as the words of Hasana Al-Tamimi (15)

To the dew and glory, my passengers walked on dusk, praying at Al-Hawajer 
Let my epilepsy cross that it is the best of Jaber and prevent me from the oppressor of Jaber

Fannie and orphaned with a fist of his palm, like feathers in the claws of a broken

The poet referred to Al-Mamdouh with a set of good qualities, and then begins by mentioning her darkness and that he is the only one who can save her from those who wanted her and her children bad for his sake of Jaber then intent on enhancing her artistic image through a scene that he derived from nature scenes in order to influence the same caliph to portray herself and her children as a weak bird who He was taken prisoner at a raptor. This is repeated in her saying (16).

My nature is good, and the oppression did not satisfy me, so there is the merit of praise of an odor that is gone

If I live in your love passion, and if I leave, you have provided me Zadi

Al-Mamdouh is the people of all praise and praise because he saved her from the injustice and injustice that befell her, so her complaint came mixed with some praise and praise.

Second: Lexia spinning dictionary

Poets have practiced this art a lot, as it is one of the most important arts that Arab poetry has known and closest to the souls of poets. Spinning is a relative concerned with describing feelings and feelings, saying towards someone who loves and likens is interested in describing the charms of the beloved. The headmaster of the Andalusian female spinning lexicon finds it occupying a large place due to the nature of social life and the nature of Andalusia at that time, which was known as openness and deviation from most of the traditions known to the East. The spinning lexicon in feminist poetry can be studied in two axes:

A- Axis lover: It is considered the engine of events as it imparts to it from its emotions and emotions, and the future is for the aesthetic effect caused by the other / adored party, what happens from its direction of the reaction, and the researcher found in the Andalusian women's spinning dictionary clear features in the embodiment of their own experience. A sad psychological and most of the word that I used is the word, which carries the moral characteristic without physical attributes such as (tampon, heartbeat, dedication to my heart, and we arrived, .....) including the words of Hafsah al-Rukuniya (17)

A displaced person was stuck in the tampon, even if the eyelids were deprived of it Saying Threshold (18)

Al-Bashir congratulated me on his link, so I gave it to myself and increased my heart for him

And the resulting irritation of these passions from these constituents, and the most visible of these words (agar, my secrets, Sabbaths, ...), as Hafsah al-Rukuniya says (19)

I am jealous of you from my eyes, from my eyes, from you, from your time and place

The poet, and because of her passion for her beloved, referred her psychological state to jealousy from herself, and this represents the pinnacle of devotion in love through this trilogy of a person adored / time/place.

And the saying of Hamdona bint Ziyad (20):

Tears legalized my secrets in a valley that has good effects in Wadi

Tears became the sign/icon of sorrow that spins the poet.

Saying Threshold (21)

You will be discreet, so whatever is discreet, you will show what you are pleased with, and he will know

And sometimes the poet resorts to employing the vocabulary of nature to express its feelings and feelings towards the adored through a natural dictionary (Wadi, Moamar, Riyadh, the River, .....) as Hafsah al-Rukuniya says (22)

For your age from the secret of Riyadh, we arrived

, but it showed us the fruits and the envy

So, if this horizon is clear, it will show its stars only to be able to observe

It is based on a mini dictionary of nature (Riyadh, Al-Faq, Al-Nujoom, .....).

In order to be an objective equation of her psychological consuls through the Mistress of Nature to depict feelings of sadness and greed 
from the eye of the sergeant who tries to monitor the retreat of the beloved by her beloved.

And the saying of Nuzhon Granada (23)

Peace opens in the flower of the mask and pronounces the branch leaves

\section{Second: adored}

The significance of the terms in this field takes a different direction from the first (adoring) field, in which sensory qualities that take the character of the material appeared in contrast to the first domain, which was often based on the moral side in highlighting the image of adoration, and perhaps this is due to the nature of Andalusian life that was based on the sensory side in most of the image Poetic, therefore, we find that the dictionary (adored) in Andalusian feminist poetry is burdened by physical/sensual connotations. You have highlighted the words (virtues, captivity, craving, your eyeballs, your luck, ....) from that of the dear nation (24)

You saw us hurt in the tampon, and we saw you hurt you in the cheeks

He was wounded with a wound, so make it similar.

What then forced the trauma?

Saying Alghasiaip (25)

And let us embrace it, and we will embrace the semen as it embraced in the wind

Often we find a lexicon of adoration adorned with the natures of nature that came to reinforce the sensual qualities of a beloved person such as the pillar sayings (26)

$A$ visitor has come in good Ghazal familiar with

the misdemeanor Crescent

Saying the Qurtubian dialect (27)

$O$ museum of peach loved ones, welcome from the snowy chest

Al-Ghaid's breasts told him he was dislodged but he disgraced heads ... (28)

The poet reflects on adding sensual qualities to describe the adored by employing the natural words in constructing her poetic image. The fruits of the peach, with their softness, and the birds with their breasted breasts are all signs that indicate the image of the adored.
As for the moral characteristics, they came in most places in a narrow range that does not exceed the image of the complaint and the reproach directed at the adored person (the lover), as the saying of the birth of Ibn Zaidoun bid him farewell (29).

If night comes after you, you can complain about the shortness of the night with you

And her saying also blames him for his love for her slave woman (30).

You knew that I was moon of the sky, but I fell in love with my sister Jupiter

In another image, we find that it intends to produce nature in drawing the image of the complaint, as it says (31).

She left a fruitful branch with its beauty and

drifted to the fruit that did not bear fruit And from you, if it was the sun, you did not press the full moon, it did not rise, and the night did not ease

All of the data are nature that the poet mentally embraced as a poem to highlight her psychological state in front of the adored.

\section{3- Glossary of spelling words:}

Spelling occupies a broad place in Arab poetry, as most poets have organized it throughout the literary ages and it depicts an emotion of anger, contempt, and mockery, whether the subject of emotion is the individual, the group, or the sects.

Andalusian literature is not devoid of this poetic purpose except that it came on a small scale and the reason for this is the development of social life at that time and the poets' preoccupation with the development of the joys of nature as well as moving away from discounts, insults, and insults as it is known in the pre-Islamic and Islamic era.

The overseer in the glossary of spelling words in Andalusian feminist poetry finds it based on the element of paradox and raises surprise and laughter sometimes with a great deal of pain and harm in a person who is abandoned out of the desire to heal and inflict harm on others. If we tried to classify the methods of satire in 
Andalusian feminist poetry as I said, we would find it divided into:

A- Depicting ugliness in form and cretinism in the form of satirists with something of ridiculous irony through a group of vocalizations (night, round, blind, and hatch)

As the saying of Nehzon of Granada in her satire to a man who got engaged to her (33)

My excuse from Atok lover fool signal and

$$
\text { disgraced }
$$

Walsal says that if he forgives, he will not forgive

\section{Fakiss's head to Kaya and a poor face to Burqa}

The poet is the mayor of depicting the obsessed with a painting that raises laughter as well as calls for contempt within the framework of the aesthetic vision by mixing between the distorted form. Spell it in the disengagement from the grip of mass ugliness. The scene is repeated in its satire of Makhzoumi, as she tried to attach a group of physical defects to it and strip it of all aesthetic and moral qualities by saying it (34).

Tell the article an article to read until it is crammed

Where Bedouin has become a lope

So I was a boy with everything rounded

She created a blind but wandered at all ...

The obsessed is the fate of every lowly and decadent moral and ethical value, how it is not, and he was created out of a lowly origin, so it has become natural to wander with all the triviality and lowliness of values and morals.

B- Insulting and slandering a derelict person: during which the poet intends to the proportion of a group of epithets that are tasted and tastes repulsed by natures, such as words (fall, dog, black, scorpions) to the derided person, this is shown in Hafsah al-Rukuniya (35).

$O$ fall of the people and $O$ humiliated them without bitter

This is the extent of the eternity readout if you come in the ball

There is no God near you, you will be blessed until you are blessed

It is that when you deliberately call the obsessed with the slightest traits and make it ugly investing the call style, which came out to the meaning of contempt to achieve this, and the matter is repeated

In her saying: (36).

Oh envelopes people before fate put him towards him

I loved black women, like the night, Bada'a Al Hassan, who was covered

Who is important in Heaven for Lanor and in it Third: A lamentable lexicon

It represents the language of afflicted emotion and the afflicted feelings of being the most poetic purposes affixed to the human psyche, and the lamentations of ancient Arab critics are a kind of praise, but it is said in the deceased (37). And following the patterns of the purpose of lamentation in Andalusian feminist poetry, it is divided into two parts:

1- Individual Lamentation: Through the expression, the poet expresses his love and loyalty to a person who occupies a prominent position in the same poet, such as being close or beloved, or because it has an influential social value, as it aims to expel the sweeping sadness that hangs in himself as a result of the loss of that dear, it is entertainment for those The calamities bite him with its teeth and the division of life between himself and her loved ones (38). We find this clearly in Hafsah al-Rukuniya's statement (39).

Guide me to wear mourning for a lover, show him to me with mourning

God have mercy on those who find tears or mourning the death of the enemy

I gave it the same kind of hands as it became from the country, Al-Ghawadi

As the poem revolves around portraying itself as a death to the one whom the dead wanted to return, so she took comfort in herself by wearing black through a group of expressions of sweeping sadness that surrounded her (mourning, tears, mourning, dead), then we find her poem wrapped by inviting listeners to mourn

$$
\text { It is too long, I treat sigma }
$$

I was not afraid to leave you. Today is your

$$
\text { departure }
$$

The poet had separated her lover, who had never imagined her mind, and he never separated her, so 
death between them made them, which made the night of the poet a bed of pain and sickness.

2- The lament of the cities: The decline of the ancient civilization that the Muslims built in Andalusia sparked a deep sorrow and sadness. It also left a deep resonance in poetry and left us the art of lamenting the cities and the passing mammals in our Andalusian literature. 41) Until the lamentations of the cities and Mamluks became one of the vital issues that carefully captivated the Andalusian poet and took his energies (42), and it was one of the most important reasons that led poets to regimes in this matter. The fall of the cities and their fall resonated in the poetry of the Andalusian woman, who was not only expressing her own feelings but went beyond that to monitoring the group's emotions and expressing the phenomenon of mass sadness through the general calamities that ravaged the masses of people in those ages.

This is evident in the statement of Al-Shalabiyya, whose Friday poem was cast on the Mansour chapel, inheriting its city (Shabab), which is the most obstructive of the western Andalusian bases. Admission after starvation and thirst for it (43), and its people left it, leaving their money and their relics and scattered in the rest of the cities say AlShalabiya (44):

\section{I sent Himla and no pasture, and I left her looting the usual seven}

Both were paralyzed and paradise was paradise returned by the tyrants a fire protector

They feared and did not fear the punishment of their Lord, and God does not hide it

The poet begins her verses by seeking the help of the prince and seeking his help, to rescue his parish, which has become like a camel that goes without a shepherd, she is at risk of Seventh, then sympathizes the scene of seeking help by mentioning her city, which the invaders referred to a lucky Yab after the paradise was like paradise. The sacred text in God Almighty's saying "Do not be hidden from God is hidden", which the Almighty legged to portray the state of the predecessors as the resurrection and a stalemate when the poet learned of the position of the Qur'anic text in the same recipient and grabbed his attention, as the poet succeeded in lamenting her city through a set of actions (a club, I sent him A, repeat, fear () that contributed to the creation of a state of dynamism in the same reader of these verses, which is similar to the transformation that struck the poet city.

The matter is repeated in saying the benefit (45), which has bemoaned the separation of Iraq and was torn apart by longing for it.

"Ali" on Baghdad, Iraq, and its antelopes and magic in its gardens.

And her shops at the Euphrates in ways that her family seems to be around.

Arrogant people in Al-Naim, as if creating the virgin passion of its morals

My redemption is for her, so any good in the world will shine brightly

The verses are crowded with the memory of the place that he had after myself with the poet, so the places that the poet is shopping like (Baghdad, Iraq, the Euphrates) are no longer present in their real dimensions, as much as semantic icons have filtered out of the memories that sow grief in the same poet that depicts their lament for those places that have touched its memory Heartbreaks are called for pain and anguish, as we find the poet begins her verses, but (aha) to depict the intensity of her misfortune and her longing for her homeland, then intends to repeat the distraction character more than (12) times to create an atmosphere of sorrow that suits the poets' groans on these countries and thus complete the elegy of the poet who turned into a painting The groans frame it from each side, then we find it The image of sadness in the same reader is strengthened by its use of the humanization mechanism of the place that it had originated and raised in its arms, a purely psychological process whose function is to influence the recipient and provoke his emotion towards the crying of the poet city, and it was deliberately intended to exaggerate the sadness of the separation of her city, as it provided us with a description Precisely for Iraq and Baghdad, which the imagination of the poet referred to a beautiful girl who was deceived by her magic with magic 
that fascinates the spectator and his magic alongside the family, who became enlightened to enlighten her forehead and her fumbling walking that indicates a kind of bliss and pleasure, and this beautiful description of Baghdad magnifies the image of sadness when it struck her when she changed her hand The two events erased its features invaders.

\section{Nature description:}

The poet is the son of his environment, from which he derives his body form and the pronouncement of his language, and it is the first inspiration for every poet, the greatest emitter of creativity. The Andalusian environment is known for its beautiful beauty, captivating beauty, and a picturesque nature in its mountains, rivers, flowers, sports, and birds. Overwhelmed by running water, trees, and capacity in conditions "(46)

And the scholar of the Andalusian woman's poetry will find that the vocabulary of nature has a clear presence in their poetic product, because of the scenes of sedition and good appearances on their country, along with the need to understand the truth of the woman/female's, producing the text of the ability to feel the beauty that makes her more attached to the vocabulary of nature, so accept They eagerly spin in their descriptions and depict their charms until nature has become symbols that point to a deeper world that can be understood through the self and the implications of it that indicate this fact. They devoted a large part of their poetry to mention nature's words in its silent and moving parts, as they benefited greatly from talents. $\mathrm{N}$ Kablathn in the filming of this environment and express their features and characteristics of a variety of ways to employ them and vocabulary animated nature of the words of Aisha Córdoban: (47)

I am a pioneer, but I do not accept myself a climate of eternity from anyone And if I choose that, I will answer a dog, and I closed my hearing about Asad. The poet in this place addresses the subject with a social dimension related to her personal choices in the field of life, as she could have resorted to a dictionary that necessarily belongs to the social system, but for some reason, she has relied on a different dictionary that reveals to the recipient that the poet lives in a diverse natural / geographical environment that helps her to select symbols You see that it is more feasible in expressing what comes from the fungus itself, as it employs (the lioness/dog/lion) symbolic employment with psychological/social connotations we see that it reflects the mood of the poet and the symbolism of these beings oscillates between the female / the desire / the fortified, which is symbolized by the lioness and the degeneration I and the lack of meaning that is symbolized by the dog, along with another parameter represented by the peer, which is equivalent to the status of the female/lioness, and which is symbolized by the lion. Aisha succeeded in blocking her desire to market a picture expressing her refusal to associate with an ordinary person symbolized by the dog, although it was required and desired by a man of social status A prestigious symbol of the lion.

In another topic, we encounter a good example of the mechanism of using living natural vocabulary as a semantic bridge that the text maker employs to wave a message whose potential cannot be easily disclosed, and this matter is illustrated in two houses of an Andalusian poet from Granada's poets, Qesmouna Bint Ismail, who says: (48)

Oaza, you always take care of your pride.

We both became alone with his friend, so let us

never persevere in the judgment of destiny.

The poet, through constructing an aesthetic approach between the doe/poet, wants to launch indicative shipments that confirm her beauty and goodness that cannot be disclosed. This mechanism that reaches the reader is a specific idea that summarizes that the second party from the sides of that aesthetic approach $=$ a person of the poet has the same characteristics of the first party $=$ doe It is similar to a simulation that the poet forgot about in the text indirectly, and so they divided it. The vocabulary of the living, fawn nature was used appropriately to show its beauty, 
in addition to expressing its psychological state, as they both suffer from isolation, which is confirmed by their similarity in sensual characteristics. And from their employment of the vocabulary of the silent nature and the flowers, fruits, rivers and night it contains, as well as the parts of water, its orbits, rain, clouds, hail, and thunder.

And from that Lance says the hearts: (49)

The night came along the day

and the full moon looked like half the bracelet.

As if the day is a cheeks page as if darkness is an excuse

As if the cups are rigid, as if the fuse was a melt of fire

The poet on the subject contemplates a scene of the silent nature/night that is presented after the day is laid off, then a set of images is formed in the imagination of the poet, where the full moon resembles half of the brilliant bracelet and that is a good image, as the silent beauty resembles the beauty of the ornament close to the same woman and this matter is repeated when similar The poet portraying the day with a cheek is a metaphor for lighting and freshness, while darkness walks as a line of excuse, but the cups and their excessive purity appear as a piece of snow.

Al-Rukuniya (586 AH), who is considered a professor of poets in her era, has resorted to the dictionary of nature to achieve her goal, which is to send a message to the Minister of Prince AbdelMumin bin Ali, who is Abu Jaafar bin AbdulMalik bin Saeed, informing him of the same barriers and fears that what surrounds them at the time of the meeting is It is merely a scene characterized by hostility, and in such a case it should not be relied upon, as it says: (50)

For your life, the happiness of Riyadh is our pleasure, but it has shown us victory and envy. And the river did not applaud as a comfort to our proximity, nor did the lunar tweet, except when it was found.

So do not improve the belief that you are his family, so what is in all citizens of adulthood
Hafsah al-Rukuniya has used the vocabulary of nature Riyadh / the river / the horizon, which belongs to the essence of the static nature to reach the desired meaning. With his stars, he accepted the role of the attending observer, for nothing but to watch the presence of the poet / text-maker with the minister.

The vocabulary of the elements of nature elements that do not exist without life without them - had a presence in the poetry of Andalusian women, because these elements have found a place in the manufacture of poetic images, with our acknowledgment that there is a philosophical dimension that can filter from those elements that dimension that has been approached by many From poets, writers, and creators, and here is Hasana Al-Tamimiyeh sweeping from this rhombus, so the elements of nature represented by (dust / the essence of man/wealth) have invested to draw a poetic image that we see as an end in perfection because it describes the human soul and is in the stage of revelation and transfiguration, so it says (51)

If the night comes, I will get a ticket, and the morning will increase my rage for me And how can an eye rest in its sociology between dirt and between the grave and the shroud? $\mathrm{He}$ wore rich and dirt on the ground. His grandmother was not a beautiful image

So, I found that the singular (soil) with its indications of a return to the truth of man is nothing but a fit to express the place of annihilation that everyone is voluntarily or forcibly going to, including her husband who removed the land from his grandmother, his beauty, and his goodness, to make it blend again through an eternal/logical relationship with the soil. From which he was created, the eyes of the haggling eyes in the darkness of the night are no longer visible to Hassan who contained the grave and the shroud because the dirt/mono silent nature insists on completing his period so erase the image of the beautiful beloved and so she was not satisfied with describing the natural scene that you see but was consuming it with her imagination 
and including it with her care to steal the nicest image and paper meaning of.

Hamdouna bint Ziyad, who was one of the people of kindness, beauty, and chastity until she was called the Khansaa al-Maghrib between our hands, explains another work in which the vocabulary of the elements of nature is invested (the sword / the torrent / the fire). In building her artistic image says: (52)

When Abu Alwashon only separated us and what I have with you and your revolt

And they waged a raid on our hearing, and my mother-in-law said then, and my supporters I invaded them from your eyeballs and prayed to myself and the sword and the torrent and the fire The poet in another matter follows the order of the tattoos who hunt any opportunity to find the difference between the poet and her lover. Which provides the poet with an enthusiastic poetic speech that fuels the image to make it suitable for the position of objecting to what the groom does

\section{Margins}

1- The Mayor: $1 / 128$

2- Looking: literature theory: 225

3- See: Al-Alberi's poetry language (College of Arts Journal): 201

4- Sees: The linguistic structure of Al-Siyab's hair: 28

5- See: Andalusian literature, its topics, and purposes: 116

6- The Mayor: 3/131

7- Looking: Poetry in the era of Almoravids and Almohads in Andalusia: 109

8- Looking at Naft Al-Tayeb: 5/300

9- Looking: briefing: 1/439

10-Looking: Nafat Al-Tayeb: 6/26

11- Seen: Adapted by Quoted: 416

12- Looking: Nafat Al-Tayeb: 5/301

13- Looking at Naifeh Al-Tayeb: 5/300

14 - Al-Qawtas Al-quoted, 413

15- Looking: Nafat Al-Tayyib: 5/300

16- Looking: Nafat Al-Tayyib: 5/301

17- Looking: Nafat Al-Tayyib: 5/308

18- Ammunition: M 1/431

19- Nafat Al-Tayyib: 5/123
20- With a view to the petitioner: 530

21- Ammunition: M 1/431

22- Naft Al-Tayyib: 5/309

23- Nafat Al-Tayyib: 5/308

24- Nafat Al-Tayyib: 5/302

25- Nafat Al-Tayyib: 6/23

26- Nafat Al-Tayyib: 5/311

27- Nafat Al-Tayyib: 6/28

28- Obscene speech

29- Ammunition: M 1/431

30- Looking: Nafat Al-Tayyib: 5/337

31- Looking: Nafat Al-Tayyib: 5/338

32- Look: satirists and satires at the forefront of Islam: 5

33- With a view to the petitioner: 530

34- Naft Al-Tayyib: 1 / 179-180

35- Nafat Al-Tayyib: 5/307

36- Naft Al-Tayyib: 6/26

37- The Mayor: 2/147

38- The End of Arabs in Literary Arts: 5/164

39- Looking: briefing: 227

40- Nafat Al-Tayyib: 4/138

41- Sees: Lamentations of cities and Mamluks in Andalusian poetry: 43

42- Looking: The Islamic trend in Andalusian poetry: 263

43- See: Al-Bayan, Morocco: 3/161

44- Nafat Al-Tayyib: 6/30

45- Nafat al-Tayyib: 4/130

46 Country Glossary: 1/262

47- Nafeh Al-Tayeb: 6/26

48 - Al-Tayyib: 5/74

49- Anfeh Al-Tayyeb: 2/146-147

50- Naft Al-Tayeb: 5 / 309-310

51- Spinning Women: 66

52- Al-Tayyeb: 5/113

\section{Conclusion}

Through this trip in the Andalusian feminist poetry, the researcher tried to light the side of the poetic lexicon in it and stand with it with some study and research by examining their literary potential and their ability to use the linguistic dictionary. The researcher reached a set of results that we summarize as follows: 
1- The poetic lexicon represents a group of vocalizations that frequently rotate in the poems of a particular poet or a group of poets until they become a stylistic feature that characterizes it, and here his poetry lies, because the poet is the master who possesses the linguistic tool fully possessing and his ability to use it aesthetic employment that brings it out of its lexical meaning to another meaning It is in keeping with the nature of its purposes and its art in a way that attracts and admires the reader.

2- The beholder in the Andalusian feminist lexical dictionary finds that the best way to deal with it is according to the poetic purposes that the poets used to explain the most important verbal dominions that are mentioned in every purpose.

3 - The purpose of praise occupied a wide area in Andalusian feminist poetry. On the level of the dictionary (Mamdouh), they turned to this purpose to the upper classes of society, who are the caliphs, princes, leaders, and the nature of this category. The poet had to choose the elegant highend words with an influential musical rhythm influencing the listener and at the level of a dictionary. (Praise) It has appeared in the form of a request for tender or complaint

4- The researcher found in the dictionary of the Andalusian woman in terms of being (a lover) of the words nodding to a sad, pleasurable psyche, as the poet is always complaining about the repercussions of her beloved and his indifference to it, and in terms of being (adored) of the words that carries a moral characteristic like (passion / longing / adultery) besides Some words that depicted the body and its organs as (to urge / eye / cheek)

5- The lexicon of individual lamentations contained the high and high words, as the Andalusian poets employed the positive words, all indicating the position of the elegy in his life and after his death, while the lexicon of the cities lamentations departed from personal subjectivity and turned to the words, arousing collective emotions expressing the state of sweeping grief that prevailed in the kingdoms And the afflicted cities that fell into the hands of the invaders
6- The Andalusian poets drafted their poetic glossary for the purpose of satire on the element of paradox and surprised, as the rhetoric was characterized by some ridiculous ridicule of the obsessed person, while the terminology included vocabulary that was tasted by tastes and repelled by natures to inflict the greatest harm on the person of the obsessed.

7 The Andalusian poets did not confine themselves to the vocabulary of nature, with its moving and static sides, to a simple external description, but rather became a symbolic equivalent to the events, feelings, and ideas that gain it indications that contribute to revealing the physical and psychological position of the Andalusian poet, as if nature takes a symbolic form of the idea presented to them.

\section{Sources and references}

[1] zslamic direction in Andalusian poetry, upholstered Mustafa Bahjah: 1st floor, Beirut, 1986

[2] Briefing on the news of Granada, Lisan Al-Din Ibn Al-Khatib, Tah Mahmoud Mahmoud Annan

[3] Dar Al-Maaref, Egypt. D. D.

[4] Andalusian literature, its topics and purposes, Dr. Mustafa Al-Shaka'a, Dar AlNahda Al-Arabia, Beirut 1972.

[5] With a view to the petitioner in the history of the men of the people of Andalusia, Ahmed bin Yahya Ahmed bin Amira AlDabi (566), Majret City, Rufus Press in $1883 \mathrm{AH}$.

[6] The statement Morocco in the news of Andalusia and Morocco by Ibn Adhari AlMarrakchi (d. 695 AH), Opened: Colan Wirvensal, House of Culture, Beirut, (D.T.).

[7] The linguistic structure of Al-Sayyab hair, d. Khalil Ibrahim Attia, Freedom House Printing, Baghdad 1986.

[8] The Quotation of the Quoted in Mentioning the Governors of Al-Andalus, Abu Abdullah Muhammad bin Abi Nasr 
Fattouh Ibn Abdullah Al-Azdi Al-Hamidi (488 AH), The Egyptian House, 1966.

[9] Ammunition in the beauties of the people of the island, Abu Al-Hassan Ali bin Bassam Al-Shantiri, Press Committee of Authorship, Translation and Prose, 1939.

[10] Lamentations of cities and Mamluks in Andalusian poetry, its attitudes and artistic characteristics d. Mahja Amin Al-Basha, Damascus, Dar Saila for Studies, Prose and Distribution 2001.

[11] Poetry in the era of Almoravids and Almohads in Andalusia, Muhammad Majeed Al-Saeed, The Arab Encyclopedia, Beirut, Lebanon, 2nd edition, 1985.

[12] The Mayor in the Laws of Poetry, Literature and Criticism, Abu Ali AlHassan Rashiq Al-Qairawani Al-Aradi (456 AH), Dar Al-Jeel, Beirut, 4th floor 1972.

[13] The spinning of women, Ain Saba, Dar AlAlam for millions of Beirut, 1st edition, 1953 AD. language of poetry by Al-Alberi d. Nafi Mahmoud, Journal of the College of Arts, 26,1990 AD.

[14] Glossary of countries, Yacout Bin Abdullah Al-Hamwi (626 AH), Dar AlFikr, Beirut, Dr.

[15] Theory of Literature, Rene Welick and Austin Warren, translated by Mohiuddin Sobhi, 3rd edition, Supreme Council for the Arts, Literature and Social Sciences, 1962.

[16] Nafeh al-Tayyib from the fine branch of al-Andalus, Ahmad bin Muhammad alMuqri al-Tilimsani (1041 AH), Muhammad Muhi al-Din Abdullah alAsadi, al-Sa dah Press, Egypt, 1st edition 1949 CE.

[17] The End of the Arabs in the Arts of Literature, Shahabuddin Ahmed bin Abdul Wahhab Al-Nuwairi, T 733 AH, a photocopy of the Dar Al Kutub Press, the Egyptian General Establishment, Costa Thomas and his partners, Cairo, D.T. 